\title{
TINJAUAN HUKUM ISLAM TENTANG PRAKTIK SEWA MENYEWA SAWAH SISTEM MASA PANEN DAN TAHUNAN DI DESA SUKARAJA KEC. PRAYA TIMUR
}

\author{
Sri Nirwana Sarowati Zikri \\ Institut Agama Islam Hamzanwadi NW Lombok Timur \\ Email: Rina_style@yahoo.com
}

\begin{abstract}
Abstrak: Tujuan dari penelitian ini adalah untuk mengetahui bagaimana tinjauan hukum islam tentang praktik sewa menyewa sawah sistem masa panen dan tahunan di Desa Sukaraja Kecamatan Praya Timur. Jenis penelitian ini menggunakan Penelitian ini merupakan penelitian lapangan (Field research) dan penelitian kepustakaan (Library Research). Hasil penelitian menunjukkan bahwa praktik sewa menyewa sawah sistem masa panen dan tahunan di Desa Sukaraja Kecamatan Praya Timur sudah sesuai dengan kajian hukum Islam yang ada, karena adanya kejelasan pembayaran setelah akad. Karena ada keterbukaan didalam perjanjian sewa sawah pada pihak penyewa dengan pihak pemilik sawah. Dan kedua belah pihak sepakat apabila dikemudian hari terjadi gagal panen yang mengakibatkan tidak berhasilnya produksi hasil dari sewa sawah tersebut maka itu tanggung jawab penyewa sawah bukan orang yang menyewakan.
\end{abstract}

Kata Kunci: Hukum Islam dan Praktik Sewa-Menyewa

\begin{abstract}
The purpose of this study is to find out how Islamic law reviews about the practice of renting rice fields during the harvest and annual systems in Sukaraja Village, Praya Timur District. This type of research is field research and library research. The results showed that the practice of renting rice fields during the harvest and annual systems in Sukaraja Village, Praya Timur District was in accordance with the existing Islamic legal studies, because of the clarity of payment after the contract. It result from there is openness in the rice field rental agreement between the tenants and the owner of the fields. And then both parties agree that if in the future there is a crop failure which results in unsuccessful production of the results of the rice field rental, it is the responsibility of the tenant, not the person who rents out.
\end{abstract}

Key words: Islamic law and leasing practice 


\section{PENDAHULUAN}

Perjanjian dalam sehari-hari tidak akan terlepas dari suatu perikatan, membeli barang menimbulkan perikatan dengan penjual, menjual barang juga menimbulkan perikatan dengan pembeli. Kalau pembelian dilakukan dengan utang maka perikatan itu tertulis berlangsung hingga uang dibayar lunas. Begitupun sewa-menyewa juga tidak akan terlepas dari perikatan, orang yang menyewakan menimbulkan perikatan dengan penyewa, begitu juga sebaliknya penyewa menimbulkan perikatan dengan orang yang menyewakan. Adapun salah satu bentuk kegiatan manusia dalam lapangan mu"amalah ialah ijarah atau sewa-menyewa yaitu suatu jenis akad untuk mengambil manfaat dengan jalan penggantian.

Belakangan ini, sudah marak dengan bermacam-macam bentuk pembiayaan, baik itu jual beli secara langsung, maupun ijarah ataupun yang lebih dikenal dengan sewa menyewa (Syafe ${ }^{e e}$ I, 2001:122). Transaksi ijarah dilandasi adanya perpindahan manfaat (hak guna), bukan perpindahan kepemilikan (hak milik). Jadi pada dasarnya prinsip ijarah sama saja dengan prinsip jual beli, tapi perbedaannya terletak pada objek transaksinya. Bila pada jual beli objek transaksinya barang, pada ijarah objek transaksinya adalah barang maupun jasa (Karim, 2008:137).

Sesuai dengan realita yang ada di lapangan, sistem praktik sewa-menyewa masih jauh dari syari'at islam, mereka melakukan sewa-menyewa sesuai kehendak- nya, seorang penyewa memberikan uang sewa kepada pemilik lahan kapanpun dia mau, kadang-kadang seorang penyewa memberikan uang sewa setengah dari perjanjian pada saat akad, kemudian baru melunasinya setelah lahan di tanami, bahkan ada pula yang memberikan uang sewa setelah panen, padahal kesepakatannya akan membayar di awal, praktik seperti ini yang membuat pihak pemilik lahan resah dan berselisih dengan pihak penyewa.

\section{METODE PENELITIAN}

\section{Desain Penelitian}

Penelitian ini merupakan penelitian lapangan (Field Research) dan penelitian kepustakaan (Library Research) jenis penelitian lapangan adalah penelitian yang bertujuan untuk mengumpulkan data dari lokasi atau lapangan, yakni dari berbagai informasi yang berkaitan dan dari buku-buku yang membahas tentang sewa menyewa dalam Hukum Islam, termasuk juga data interview dengan para pihak yang bersangkutan sebagai objek penelitian. penelitian kepustakaan yaitu penelitian yang bertujuan untuk mengumpulkan data dan informasi dengan bantuan berbagai macam materi yang terdapat diruang perpustakaan.

\section{Populasi dan Sampel}

Populasi yaitu keseluruhan subjek penelitian. Sedangkan menurut sudjana. "populasi adalah totalitas semua nilai yang mungkin hasilnya menghitung atau pengukur kuantitatif maupun kualitatif mengenai 
karakteristik tertentu dari semua anggota kumpulan yang lengkap dan jelas yang ingin dipelajari sifat-sifatnya." Apabila seseorang ingin meneliti semua elemen yang ada di wilayah penelitian, maka penelitian ini merupakan penelitian populasi. Adapun populasi dalam penelitian ini yang berjumlah 40 orang sebagai pemilik tanah dan penyewa tanah.

Sampel adalah sebagian atau wakil dari populasi yang akan di teliti. adapun sampel dalam penelitian ini yang berjumlah 11 orang sebagai pemilik tanah dan penyewa tanah yang terbagi 5 orang sebagai penyewa tanah dan 6 orang sebagai pemilik tanah.

\section{Tekhnik Analisa Data}

Data yang di kumpulkan menggunakan metode pengumpulan data yang telah disebutkan diatas lalu diolah yaitu dipilih-pilih dan di kelompokkan menurut jenisnya masing-masing, yaitu data tentang bentuk upaya, materi, metode, bentuk pembinaan, baik didapat dari interview, observasi maupun dokumentasi, sesudah data diolah kemudian dianalisis. Apabila data sudah terkumpul secara keseluruhan kemudian dilakukan kualitatif dengan menggunakan metode deduktif. Cara berfikir deduktif yaitu dengan cara bermula dari data yang bersifat umum tersebut ditarik kesimpulan yang bersifat khusus.

\section{PEMBAHASAN}

Hasil penelitian menunjukkan bahwa sewa menyewa sawah yang akan ini merupakan praktek sewa menyewa atas kemauan kedua belah pihak. Karena mayoritas penduduknya merupakan petani yang kegiatan sehari-harinya menggarap sawah, maka praktek sewa lahan pertanian sudah menjadi kewajaran di desa. Bagi masyarakat yang tidak mempunyai lahan pertanian maka kemudian mereka melakukan sewa kepada masyarakat yang mempunyai lahan yang tidak digarap atau memang dari pemilik lahan tersebut ingin disewakan.

Sewa sawah yang terjadi di Desa Sukaraja merupakan suatu akad sewa terhadap manfaat suatu sawah untuk diambil manfaatnya dalam beberapa kali panen atau beberapa tahun yang telah ditentukan dan dengan imbalan yang tertentu pula. Sewa menyewa ini biasa diadakan satu atau dua kali panen, dimana uang sewa dibayar pada saat akad, namun ada pula yang membayar setelah tanam, padahal kesepakatan-nya pada saat akad. Harga sewa biasanya disesuaikan dengan ukuran tanah yang akan digarap oleh penyewa.

Mereka biasanya menyewa sawah pada musim kemarau, para penyewa memanfaatkan sawah sewa sebagai tempat menanam tembakau, para penyewa memilih menanam tembakau karena hasilnya cukup besar. Akan tetapi ada juga yang menyewa sistem tahunan, misalnya satu tahun, dua tahun, bahkan ada juga yang sampai tiga tahun. Di desa sukaraja Kecamatan Praya Timur Kabupaten Lombok Tengah ada dua musim, ada musim hujan dan ada musim 
kemarau. Ketika musim hujan biasanya para petani menanam padi sebagai kebutuhan pokok dan modal hidup, dan pada musim kemarau para petani menanam tembakau dan tanam-tanaman lainnya.

Berdasarkan hasil penelitian ditemukan secara garis besar praktek sewa sawah yang dilakukan masyarakat setempat adalah sistem sewa sawahmasa panen dan tahunan. Dalam praktik sewa sawah di Desa Sukaraja Kecamatan Praya TimurKabupaten Lombok Tengah, motivasi para pelaku tidak dalam keadaan terpaksa, bahkan ada yang menyewakan swahnya untuk memenuhi kebutuhan tersier mereka. Hanya ada beberapa pelaku yang menyewakan swahnya karena adanya kebutuhan mendadak, tetapi mereka masih memiliki jalan lain untuk memenuhi kebutuhannya misalnya dengan berhutang.

Objek sewa disyaratkan dapat dimanfaatkan dengan sempurna sampai kepada masa yang disepakati, Dalam pelaksanaan akad sewa sawah di Desa Sukaraja Kecamatan Praya Timur Kabupaten Lombok Tengah Penyewa dengan pasti dapat memanfaatkan tanah sewa tersebut. Sementara mengenai proses yang terjadi pada masyarakat hanya antara masyarakat Sukaraja setempat saja. Masalah akad yang dilakukan secara lisan saja atau atas dasar suka sama suka dan rela sama rela yaitu dengan cara pemilik sawah atau si penyewa yang mendatangi rumah dan menyampaikan keinginan untuk menyewa sawah tersebut.
Akan tetapi cukup antara kedua belah pihak saja.

Dengan demikian setelah terjadinya akad tentang sewa sawah timbullah hak dan kewajiban bagi pemilik sawah dan penyewa sesuai dengan kesepakatan dan keseriusan antara kedua belah pihak. Tentang batas waktu sistem praktek sewa sawah adalah sesuai dengan kesepakatan awal dalam suatu akad, dan dalam hal ini kesepakatan yang dihasilkan berkisar dua sampai tiga kali panen.

Cara pelaksanaan sewa sawah di Desa Sukaraja Kecamatan Praya Timur Kabupaten Lombok Tengah tidak jauh berbeda dengan pelaksaan sewa sawah pada umumnya. Sewa sawah yang terjadi di Desa Sukaraja Kecamatan Praya Timur Kabupaten Lombok Tengah merupakan suatu akad sewa menyewa terhadap manfaat suatu sawah untuk diambil manfaatnya dalam beberapa musim yang telah ditentukan dan dengan imbalan yang tertentu pula. Jenis tanaman yang biasa disewakan anatara lain padi, jagung, tembakau dan sayuran. Akad sewa menyewa diadakan disaat sebelum tanam dimulai dimana saat itu kedua belah pihak sepakat untuk mengadakan akad sewa musim pertama. Peninjauan pun diadakan pada saat akad tersebut, dan penyewa memperkirakan kisaran harga sewa dari luas tanah dan kesuburan tanah tersebut. Setelah kedua belah pihak mengadakan penawaran dan peninjauan, maka tahap selanjutnya adalah tahap transaksi. Harga ditetapkan setelah melalui proses tawar- 
menawar antara kedua belah pihak. Ijab dan qabul dinyatakan secara lisan dengan menggunakan kata-kata yang terang, jelas dan dapat dimengerti oleh kedua belah pihak.

Tinjauan hukum Islam tentang praktik sewa menyewa sawah sistem masa panen dan tahunan di Desa Sukaraja Kecamatan Praya Timur yaitu Hampir semua ulama fikih sepakat bahwa ijarah disyariatkan dalam islam. Adapun golongan yang tidak menyepakatinya, seperti Abu Bakar AlAsham, isma'il bin Aliyah, Hasan Al-Bashri, Al-qasyani, Nahrawani,dan Ibnu Kisan. Mereka tidak membolehkan ijarah, karena ijarah adalah jual beli manfaat, sedangkan manfaat pada saat dilakukannya akad, tidak bisa diserah terimakan, setelah beberapa waktu barulah manfaat itu dapat dinikmati sedikit demi sedikit, sedangkan sesuatuyang tidak ada pada waktu akad tidak boleh diperjualbelikan. Dalam menjawab pandangan ulama yang tidak menyepakati ijarah tersebut. Ibnu Rusyd berpendapat bahwa kemanfaatanwalaupun tidak berbentuk, dapat dijadikan alat pembayaran menurut kebiasaan (adat) (Muslich, 2010).

\section{SIMPULAN}

Sewa menyewa sawah sistem masa panen dan tahunan di Desa Sukaraja Kecamatan Praya Timur Kabupaten Lombok Tengah ini sering dilakukan oleh masyarakat setempat. Sewa menyewa sawah sistem masa panen dan tahunan ini terjadi melalui suatu akad ijab dan qabul yang dilaksanakan dengan cara lisan antara pemilik lahan sawah dengan penyewa sawah, baik itu berkaitan dengan harga dan banyaknya masa panen yang disewa. Akan tetapi dalam akad tidak disebutkan berapa lama waktu untuk menggarapnya dalam hitungan hari bulan ataupun tahun, hanya ditetapkan banyaknya masa panen saja.

Adapun pembayaran uang sewa dilakukan di awal akad pada saat akad. Dan mengenai harga sewa di sepakati oleh kedua belah pihak. Jadi kesimpulannya mengenai waktu sewanya jelas yaitu sesuai dengan perjanjian sampai berapa kali panen di perjanjian tersebut. Adapun pelaksanaan sewa-menyewa sawah sistem masa panen dan tahunan di Desa Sukaraja Kecamatan Praya Timur Kabupaten Lombok Tengah menurut hukum Islam yang bersumber dari al-Qurean, as-Sunnah dan ijma tentang sewa menyewa, maka sewa menyewa sawah sistem masa panen dan tahunan di Desa Sukaraja Kecamatan Praya Timur Kabupaten Lombok Tengah dipandang sah dan dibenarkan. Dilihat dari segi rukun sewa menyewa, tidak ada kecacatan dalam rukunnya. Dalam sewa menyewa disini akadnya hanya di awal saja, satu kali akad untuk penyewaan sampai sesuai yang disepakati oleh kedua belah pihak.

\section{DAFTAR PUSTAKA}

Anshori, Abdulgofur. 2010. Hukum perjanjian islam di Indonesia. Yogyakarta: Gadjahmada University Press. 
Al-Faifi, Syaikh Sulaiman. 2017. Ringkasan Fiqih Sunnah. Depok: Senja Media Utama.

Arikunto, Suharsimi. 1996. Prosedur Penelitian Suatu Pendekatan Praktek. Jakarta: Rineka Cipta.

Ash-Shiddieqy, Hasbi. 2001. Falsafah Hukum Islam. Semarang: PT. Pustaka Rizki Putra.

Aziz, Moh. Saifullah Al. 2005. Fiqih Islam. Surabaya: Terbit Terang.

Chairuman, Pasaribu. 2015. Hukum Perjanjian Dalam Islam. Jakarta: Sinar Grafika.

Departemen Pendidikan Nasional. 2011. Kamus Besar Bahasa Indonesia, Edisi Keempat. Jakarta: Gramedia Pustaka Utama.

Dewi, Gemala dan Widyaningsih. 2005. Hukum Perikatan Islam di Indonesia. Jakarta: Prenada Media Grop.

Ghazali, Abdul Rahman, dkk. 2010. Fiqh muamalah. Jakarta: Kencana.

Huda, Qomarul. 2011. Fiqih Muamalah. Yogyakarta: Penerbit Teras.

Lbib Mz. 2006. Etika Bisnis Islam. Surabaya:: Bintang Usaha Jaya.

M.Hasbi Assidiqy. 2002. Falsapah Hukum Islam. Jakarta: Gramedia Pustaka Utama.

Mardani. 2012. Fiqhekonomi syari'ah. Jakarta: Kencana Media Group.

Mas'adi, Ghufron A., Fiqh Muamalah Kontekstual, PT. Raja Grafindo Persada, Jakarta, 2002

Munawwir, A.W. 1984. Kamus Munawwir Arab Indonesia Terlengkap. Yogyakarta: Pustaka Progressif,
Muslih wardi. 2010. Fiqh muamalat. Jakarta: Sinar Grafika.

Rully dan poppy. 2014. Metodelogi Penelitian. Bandung: PT. Refikaaditama.

Sugiyono. 2018. Metode Penelitian Pendidikan. Bandung: Alfabeta.

Wahbah, Az-Zuhaili. 2011. Fikih Islam Wa Adillatuhu. Jakarta: Gema Insani 